\title{
The Influence of Experiential Quality, Excitement, Museum Image, and Experiential Satisfaction toward Revisit Intention (The Empirical Study at Modern and Contemporary Art Museum in Jakarta)
}

\author{
Dwina Deandra Subroto', Arga Hananto² \\ ${ }^{1}$ Master of Management, Faculty of Economy and Business, Universitas Indonesia \\ ${ }^{2}$ Management Department, Faculty of Economy and Business, Universitas Indonesia
}

\begin{abstract}
This study attempts to identify four primary dimensions of experiential quality in the art museum and examine the interrelationship between the experiential quality dimensions, experiential quality, excitement, equity, experiential satisfaction, and revisit intention. As a framework, the researcher used a multi-dimensional and hierarchical model to test the relationship among those variables. The researcher used a quantitative method with CB-SEM on a convenience sample of 306 respondents from the museum's visitors. This research showed that interaction quality, physical environment quality, outcome quality, and access quality positively affect visitors' judgment on experiential quality. Experiential quality also has a vital role in affecting excitement and museum image, which will lead to experiential satisfaction and revisit intention, respectively.
\end{abstract}

Keywords: Marketing, Experiential Quality, Excitement, Museum Image, Experiential Satisfaction, Revisit Intention

\section{Introduction}

In the period 2013-2018, the number of domestic tourism in Indonesia has grown by $21 \%$. The head of the ministry of public communication bureau found that millennials were dominating the local tourists. [1] Therefore, the government believes that it is essential to pay attention to millennials as they are a potential target for the tourism industry. The Ministry of Tourism works together with the Ministry of Education and Culture to make museums as the mainstay of the national tourist attraction. [2] One museum in Indonesia that is considered quite successful in attracting the attention of millennials by the Coordinating Minister for Maritime Affairs is the Modern and Contemporary Art of Nusantara (MACAN) Museum. This remarkable judgment build upon TIME Magazine assessment, where this art museum was categorized as one of the Best Places to Visit, beating other unique places in 48 countries [3] Based on a former study, any activities of tourism can be regarded as experiential consumption. [4] However, the satisfaction and intentions resulting from the experience may be defined by some factors. For instance, Lotz et al. believe that excitement is related to experiential quality. [5] Jin et al. also found that the customers' quality of experience positively affects the image of the service provider. [6] Studies have also highlighted the consequences of experiential quality and excitement. Lai et al. found that the evaluation of experiential quality can lead to a positive evaluation of a company's image and increases revisit intention. [7] Meanwhile, as the visitor feels excitement, the visitor would be satisfied with the experience. [8] 
This study is intended to investigate the role of experiential quality, excitement and museum image in affecting museum visitors' experiential satisfaction and revisit intention. This study attempted to examine the experiential quality using the perspective proposed by Brady and Cronin who conceptualized experiential quality as a hierarchical and multidimensional construct, which seems to be more holistic in capturing the whole concept of experiential quality. [9]

This study's contribution is twofold. First, it presents a validation of hierarchical and multidimensional experiential quality construct in a different geographical area. Secondly, this study attempted to provide insights as to whether Indonesian museum visitors responds to experiential quality cues provided by a modern and contemporary art museum. The authors selected MACAN Museum due to its high number of visitors per year. In addition, initial focus group interviews conducted by the authors has indicated that the museum exhibits experiential quality, thus it deemed appropriate as a study context.

\section{Literature Review}

\subsection{Experiential Quality}

Experiential quality is defined as a perceived assessment of the excellence of product consumption based on customer experience. [10] The measurement of experiential quality is subjective, where each visitor could have different perceptions about their experiential quality based on their deep feelings. [11] In the tourism industry, service quality refers to the service performance of existing attributes, where experiential quality refers to the psychological results obtained from tourism activities. [4] Several researchers indicate that experiential quality is better measured based on several multi-dimensional and hierarchical models' perceptions of experiential quality. [9] [12] [13] The dimensions of experiential quality must be adjusted back to the conditions that exist in the intended research object. [12] Interaction quality, physical environment quality, outcome quality, and access quality assessed as the four primary dimensions of experiential quality that best fit the object of this study. [4] Several researchers also suggest using formative constructs rather than in traditional construct, with hierarchical models on experiential quality. [9] [12] [4]

\subsection{Excitement}

Excitement has a definition as a combination of immense pleasure and arousal. [14] Ramaseshan and Tsao indicate that excitement is considered to have a strong association with perceived quality. [15] Excitement is seen as one of the characteristics of a brand which defined as a form of character that is different from other characters, with high imagination to create innovation. [16]

\subsection{Museum Image}

Image was described by a former study as a combination of beliefs, thoughts, and impressions obtained by consumers towards a tourist destination or place. [17] According to some researches [18] [19], image is generally used as an important factor to determine customer perceptions, quality, satisfaction, and revisit intention. The museum's image refers to consumers' perceptions of the museum that arises from the emotional response felt by 
consumers and perceptions that are influenced by previous experiences or initial information obtained by consumers about the museum. [20]

\subsection{Experiential Satisfaction}

Satisfaction is defined as a customers' thought that is needed, desired, and expected by consumers about a product and service that could lead to forming a future repurchase and loyalty. [21] Experiential satisfaction is a form of development of service satisfaction. Experiential satisfaction focuses on an evaluation of consumers in general based on their experiences after consuming compared to their expectations. Emotions that arise are a response based on cognitive consistency or dissonance with the final result that is a form of satisfaction or dissatisfaction. [22]

\subsection{Revisit Intention}

Revisit intention can be described as a possibility to revisit a place as a positive behavior towards the service offered. [23] Revisit intention felt by a large number of visitors is likely to be influenced by the performance of the destination, efforts to promote tourist attractions, and also news about new things from the tourist attractions. [24] Based on several studies, the most crucial factor affecting the revisit intention of visitors is satisfaction. [25] Satisfying visitors is considered to have great importance because it can affect the expectations and intentions of visitors to decide to return to visiting tourist attractions. [26]

\subsection{Research Model}

The researcher uses a hierarchical model to analyze the relationships between experiential quality, excitement, museum image, experiential satisfaction, and revisit intention. [9] [12] [4] The study also uses a multidimensional experiential quality model with four primary dimensions (interaction quality, physical environment quality, outcome quality, and access quality) and sub-dimensions. According to several studies, experiential quality dimensions and sub-dimensions must be adjusted to the research object. [12] [4] For this reason, researchers conducted focus group interviews to determine research subdimensions.

Overall, this research has a significant contribution to examining the relationship between experiential quality, excitement, museum image, experiential satisfaction, and revisit intention in the museum industry. This study will overcome several weaknesses of traditional SERVQUAL by using a multidimensional and hierarchical research model.

\subsection{Hypothesis}

The hypothesizes in this study are (H1) Experiential Quality has a positive influence on Excitement; (H2) Excitement has a positive influence on Experiential Satisfaction; (H3) Experiential Quality has a positive influence on Experiential Satisfaction; (H4) Experiential Quality has a positive influence on Image Museum; (H5) Image Museum has a positive influence on Experiential Satisfaction; (H6) Experiential Satisfaction has a positive influence on Revisit Intention; (H7) Museum Image has a positive influence on Revisit Intention. These hypotheses are summarized in figure 1 . 


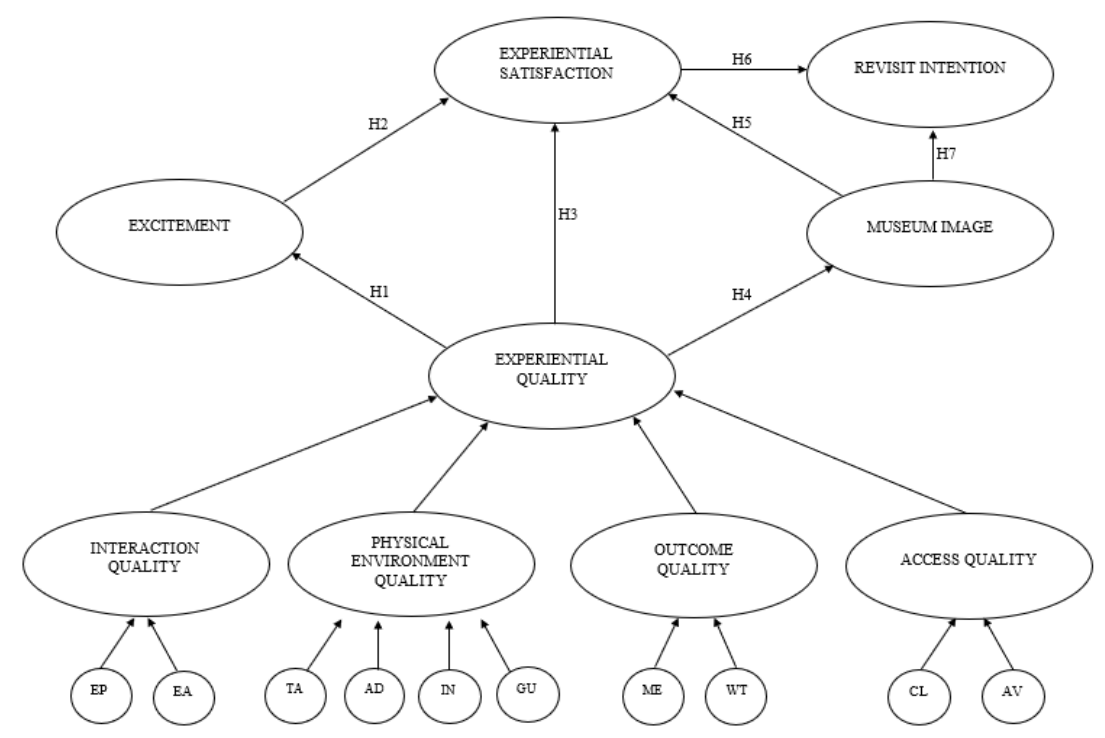

Notes: $\mathrm{EP}=$ Employees' Performance, $\mathrm{EA}=$ Employees' Ability, $\mathrm{TA}=$ Tangibles, $\mathrm{AD}=$ Ambience $\&$ Design, $\mathrm{IN}=$ Information, $\mathrm{GU}=$ Guidance, $\mathrm{ME}=$ Museum Experience, $\mathrm{WT}=$ Waiting Time, $\mathrm{CL}=$ Convenience Location, AV = Accessible Venue

Fig.1. A conceptual research model

\section{Method}

The research model has been modified to have the best explanation of the museum industry. The modification includes some changes in sub-dimensions and several main variables. Adjustments made by changing some of the variables used. This study uses the excitement variable because excitement is believed to be a form of emotion, which is the primary key to consumer experience during the delivery of a service. [5] This study also uses the museum image variable because the museum image is used as an essential factor to shape consumer perceptions about service quality and customer satisfaction. the desire of consumers to come to where the service is offered again. [27] The variable Revisit Intention is also used because this variable is a continuation of satisfaction. [28]

To provide some changes, this study was preceded by a focus group interviews with MACAN Museum visitors to confirm experiential quality dimensions and identify experiential quality sub-dimensions exhibited by the MACAN Museum. Once the dimensions, subdimensions, and measurement items were confirmed, the study proceeded with pre-test, and subsequently the main survey.

Sample in this study consists of people who visited MACAN Museum in the last six months. Respondents were selected using convenience sampling technique due to a lack of available sampling frame. Convenience sampling is a type of nonprobability sampling where the sample from the population have practical criteria. [29] In this case, those samples were chosen due to their easiness to access and their willingness to participate. A total of 352 responses were recorded. From the total, there were 306 usable responses that were used in the subsequent data analysis stage. 


\section{Result And Discussion}

Before the main survey, a small sample of 33 respondents were used for pretesting, and 8 people for occurring a wording test. The pretest indicated that all items satisfied cronbach's alpha of $0.6, \mathrm{KMO}>0.50$, and factor loading $>0.50$. The result of the pretest shows that the measuring instruments are valid and reliable.

After conducting a pretest, the researcher analyzed the main sample in IBM SPSS AMOS software. According to Mahfud and Ratmono explanation, two stages need to be carried out in analyzing CB-SEM, namely confirming the measurement model (Confirmatory Factor Analysis), then evaluating the structural model. [30] In CFA analysis, the author has to analyzed the reliability and validity to ensure the accuracy and consistency of the instruments. The authors tested the reliability and validity of every variable (including experiential quality sub-dimensions, experiential quality primary dimensions, experiential quality, excitement, experiential satisfaction, and revisit intention). In testing internal reliability and validity, researchers pay attention to the value of composite reliability, AVE (Average Variance Extracted), and factor loading. Reliability values between 0.50 and 0.75 are considered moderate. Reliability values between 0.70 to 0.90 are considered satisfactory to excellent. [31] Meanwhile, the Average Variance Extracted value with a minimum limit of 0.40 can still be accepted as a validity provision. [32] The factor loading values must be above 0.50. [33] The results of reliability testing on the main sample indicate that all variables have a composite reliability values of 0.784 to 0.917 . The results also show that the AVE value on all variables is 0.496 to 0.614 , and the factor loading value on all variables is 0.565 to 0.820 . Because all of the values are matching with all of the criteria, it can be concluded that all indicators and variables used in the study are valid and reliable.

After the researcher carries out the reliability and validity test, the researcher assessed the goodness of fit to test the predictive capability of the research model and the relationships between constructs. There are several indiractors that could be used by the author to measure the goodness of fit, which are Goodness of Fit Index (GIF), Root Mean Square Error of Approximation (RMSEA), Root Mean Square Residual (RMR), Normed Fit Index (NFI), Comparative Fit Index (CFI), Relative Fit Index (RFI), and Incremental Fit Index (IFI). [34]

Table 1. The overall fit of the srtuctural model

\begin{tabular}{ccccccccc}
\hline Model & CMIN/DF & P & RMSEA & RMR & CFI & GFI & IFI & NFI \\
\hline $\begin{array}{c}\text { Measurement } \\
\quad \begin{array}{l}\text { Model } \\
\text { Structural Model - }\end{array}\end{array}$ & 2,449 & 0,000 & 0,069 & 0,003 & 0,999 & 0,997 & 0,999 & 0,998 \\
$\quad \begin{array}{l}\text { Overall Model } \\
\text { Recommended Value }\end{array}$ & $<3,449$ & 0,000 & 0,050 & 0,000 & 1,000 & 1,000 & 1,000 & 1,000 \\
\hline
\end{tabular}

At first, the author conducted the overall fit of measurement model. The study shows an acceptable $\mathrm{CMIN} / \mathrm{DF}$ ratio, because it is less than $3(\mathrm{CMIN} / \mathrm{DF}=2,449)$. The other indicators of goodness of fit are RMSEA $=0,056$, RMR $=0,024$, CFI $=0,97$, GFI $=0,945$, IFI $=0,970$, and NFI $=0,941$. These indicators show a good fit of measurement model. The next step is conducting the overall fit of structural model. As shown in Table 1, the overall fit of the measurement model is acceptable (RMSEA $=0,069$, $\mathrm{RMR}=0,003, \mathrm{CFI}=0,999, \mathrm{GFI}=0,997, \mathrm{IFI}=0,999$, and NFI $=0,998$ )

Table 2. The relations of subdimensions \& dimensions of Experiential Quality

\begin{tabular}{|c|c|c|c|}
\hline Relations & $\beta$ Values & $T$ - Value $\quad(>1.65)$ & $P$ - Value $(<0.05)$ \\
\hline $\mathrm{EP} \rightarrow \mathrm{IQ}$ & 0.242 & 2.116 & 0.034 \\
\hline $\mathbf{E A} \rightarrow \mathbf{I Q}$ & 0.723 & 5.309 & 0.000 \\
\hline
\end{tabular}




\begin{tabular}{|c|c|c|c|}
\hline TA $\rightarrow$ PEQ & 0.390 & 2.960 & 0.003 \\
\hline AD $\rightarrow$ PEQ & 0.481 & 2.949 & 0.003 \\
\hline IN $\rightarrow$ PEQ & 0.109 & 1.153 & 0.153 \\
\hline GU $\rightarrow$ PEQ & 0.243 & 3.150 & 0.002 \\
\hline $\mathrm{ME} \rightarrow \mathrm{OQ}$ & 0.643 & 9.657 & 0.000 \\
\hline $\mathbf{W T} \rightarrow \mathbf{O Q}$ & 0.311 & 4.970 & 0.000 \\
\hline $\mathbf{C L} \rightarrow \mathbf{A Q}$ & 0,240 & 10.953 & 0.000 \\
\hline $\mathbf{A V} \rightarrow \mathbf{A Q}$ & 0.762 & 10.953 & 0.000 \\
\hline $\mathrm{IQ} \rightarrow \mathrm{EQ}$ & 0.870 & 5.389 & 0.000 \\
\hline PEQ $\rightarrow$ EQ & 0.271 & 2.722 & 0.006 \\
\hline $\mathrm{OQ} \rightarrow \mathrm{EQ}$ & 0.549 & 5.143 & 0.000 \\
\hline $\mathbf{A Q} \rightarrow \mathbf{E Q}$ & 0.150 & 2.352 & 0.019 \\
\hline
\end{tabular}

The next step after the author implement the confirmatory factor analysis, the hypothesis analysis was conducted. Data analysis also confirmed the structure of experiential quality. From table 2, it can be seen that all subdimensions (except for information subdimension) were associated with its corresponding primary dimensions of experiential quality. Furthermore, all primary dimensions of experiential quality used in this study were associated with experiential quality.

After carrying out the structural model assessment and confirmation of experiential quality structure, the authors proceeded with hypothesis testing. The parameters used are standardized $\beta$ co-efficient, T-Statistic, and p-value. Based on Table 3, all hypotheses had a T-test value $>$ 1.65 , and $p$-values $<0.05$. For this reason, all of the hypotheses were supported by the data.

Table 3. The results of hypothesis testing

\begin{tabular}{ccccc}
\hline \multicolumn{2}{c}{ Hypothesis } & $\boldsymbol{\beta}$ Values & $\begin{array}{c}\text { T } \text { - Test } \\
(>\mathbf{1 . 6 5})\end{array}$ & $\begin{array}{c}\text { P }- \text { Value } \\
(<\mathbf{0 . 0 5})\end{array}$ \\
\hline $\mathrm{H} 1$ & $\mathrm{EQ} \rightarrow \mathrm{EX}$ & 0.734 & 18.585 & 0.000 \\
$\mathrm{H} 2$ & $\mathrm{EX} \rightarrow$ ES & 0.412 & 6.944 & 0.000 \\
$\mathrm{H} 3$ & $\mathrm{EQ} \rightarrow \mathrm{ES}$ & 0.496 & 4.309 & 0.000 \\
$\mathrm{H} 4$ & $\mathrm{EQ} \rightarrow \mathrm{MI}$ & 0.740 & 19.237 & 0.000 \\
$\mathrm{H} 5$ & $\mathrm{MI} \rightarrow \mathrm{ES}$ & 0.168 & 3.026 & 0.020 \\
$\mathrm{H} 6$ & $\mathrm{ES} \rightarrow \mathrm{RI}$ & 0.532 & 10.627 & 0.000 \\
$\mathrm{H} 7$ & $\mathrm{MI} \rightarrow \mathrm{RI}$ & 0.454 & 5.075 & 0.000 \\
\hline
\end{tabular}

From the test results, the Experiential Quality variable had the greatest positive influence on the Excitement variable $(\beta=0.734, \mathrm{~T}=18.585, \mathrm{p}<0.000)$. This result was supported by the research that was conducted by $\mathrm{Wu}$ et al. (2016). The authors also found that Experiential Satisfaction has a positive impact on Revisit Intention $(\beta=0.532, \mathrm{~T}=10.627, \mathrm{p}<0.000)$ which is the same with the assumption of several former research. [13]

\section{Conclusion}

After six months of executing the research, the researcher could make a conclusion that was drawn based on the relationship between Experiential Quality, Excitement, Experiential Satisfaction, Museum Image, and Revisit Intention variables. Based on the testing that has been carried out, Experiential Quality can positively influence Excitement, Experiential Satisfaction, and Museum Image. The researcher found that Experiential Quality has the most 
significant influence on Excitement. This result is the same as earlier studies, where they indicated that perceived quality has a positive impact on Excitement. [33] A former study assumed that the service quality dimensions have a positive impact on Excitement. [15] This study also found that Excitement became the most significant mediator between Experiential Quality and Experiential Satisfaction.

In addition, this study's result indicates that the average respondent agrees with the statement that the experience they get from Museum MACAN is exciting and quite fun. This positive feeling follows the Experiential Satisfaction variable's mean result, which states that they have a pleasant experience. Experiential Quality is known as the most crucial predictor of Experiential Satisfaction. [12] [6]

Based on this research, visitors find their experience at Museum MACAN interesting, fun, and educational, so they agree that Museum MACAN is superior to other museums. The indicator used in the Experiential Quality variable is closely related to the indicator in the Image Museum, which talks about how MACAN Museum has excellent service and reputation for providing art education through the works that are exhibited to visitors. Experiential Quality has a direct impact on the company's image. [35]

A positive effect was also seen in the Museum Image variable on Experiential Satisfaction. On average, respondents agree that the image of Museum MACAN is excellent, and their experience is beyond expectations, so they are happy with the visit that has been carried out. Tourists who believe that the service they get is excellent, and the organization has a positive overall image will form a good feeling because the experience they get is enjoyable, useful, to the point that it is beyond expectations. This result has also proven by Kim and Jin, where emotion that was appeared because of the Excitement was considered as satisfaction. [36] It can be conclude that company's image is one of the most important factors to identify customers' satisfaction. [6]

Variable Museum Image and Experiential Satisfaction eventually can form Revisit Intention. The study shows that respondents agreed that most respondents were happy with their visit and would come back whenever possible. The Experiential Satisfaction variable also plays a significant role as a mediator in the relationship between the Experiential Quality variable and Revisit Intention; the relationship between Excitement and Revisit Intention; Museum Image's relationship with Revisit Intention. Respondent profile data also support Museum MACAN's excellent performance to convey a good art education experience. It states that $12 \%$ of respondents admit that they have the primary purpose of visiting Museum MACAN to study the artworks on display.

This result is supported by a number of former studies. The customers' evaluation of the service will affect the company's image, resulting in an intension to revisit. [7] One of marketing studies found that customers will do a rebuy if they are satisfied with their consumption experience. [37]

\section{References}

[1] Zuhriyah, D. A.: Kemenpar Bidik 275 Juta Pergerakan Wisatawan Nusantara Tahun Ini. Bisnis.com, 10 September 2019. [Online]. Available: https://ekonomi.bisnis.com/read/20190910/12/1146568/kemenpar-bidik-275-juta-pergerakanwisatawan-nusantara-tahun-ini. 
[2] Oktaveri, J. A.: DPR: Perkuat Data, Jadikan Museum Objek Wisata Andalan. Bisnis.com, 17 Mei 2017. [Online]. Available: https://kabar24.bisnis.com/read/20170517/79/654593/dpr-perkuat-datajadikan-museum-objek-wisata-andalan.

[3] Anjungroso, F. : Museum Macan Dinobatkan Jadi Tempat Terbaik di Dunia Versi Majalah TIME. Tribun Bisnis, 26 Agustus 2018. [Online]. Available:

http://www.tribunnews.com/bisnis/2018/08/26/museum-macan-dinobatkan-jadi-tempat-terbaik-didunia-versi-majalah-time.

[4] Wu, H., Ai, C., and Cheng, C.: Synthesizing the effects of green experiential quality, green quality, green image, and green experiential satisfaction on green switching intention. International Journal of Contemporary Hospitality Management, pp. 2080-2107 (2016)

[5] Lotz, S., Eastwick, A., and Shim, S.: Modeling participation in entertainment and shopping activities in malls utilizing the flow paradigm, Seoul: The Paper Presented at Yonsei Universirty (1999)

[6] Jin, N. P., Lee, S., and Lee, H.: The effect of experience quality on perceived value, satisfaction, image, and behavioral intention of Water Park Patsons: New versus repeat visitors, International Journal of Tourism Research, (2015)

[7] Lai, F., Babin, B. and Griffin, M.: How quality, value, image, and satisfaction create loyalty at a Chinese telecom, Journal of Business Research, pp. 980-986 (2009)

[8] Mano, H. and Oliver, R.: Assessing the dimensionality and structure of the consumption experience: Evaluation, feeling, and satisfaction, Journal of Consumer Research (1993)

[9] Brady, M. and Cronin, J.: Some new thoughts on conceptualizing perceived service quality: A hierarchical approach, Journal of Marketing (2001)

[10] Lemke, Clark and Wilson, H.: Customer experience quality: An exploration in business and consumer contexts using repertory grid technique, Journal of the Academy Marketing Science (2011)

[11] Chen, C. F. and Chen, F. S.: Experience quality, perceived value, satisfaction, and behavioral intentions for heritage tourists, Tourism Management (2010)

[12] Wu, H. and Li, T.: A study of experiential quality, perceived value, heritage image, experiential satisfaction, and behavioral intentions for heritage tourists, Journal of Hospitality \& Tourism Research, (2014)

[13] Wu, H., Wong, W., and Cheng, C.: An empirical study of behavioral intentions in the food festival: The case of Macau, Asia Pacific Journal of Tourism Research, (2014)

[14] Liljander V. and Bergenwall, M. Consumption-based emotional responses related to satisfaction, Helsinki, Finland: Swedish School of Economics and Business Administration, (1999)

[15] Ramaseshan, B. and Tsao, H.: Moderating effects of the brand conception the relationship between brand personality and perceived quality, Journal of Brand Management, p. 458, (2007)

[16] Kotler, P. and Keller, K. L.: Manajemen Pemasaran Buku I, Jakarta: Erlangga, (2009)

[17] Baloglu, S. and Brinberg, D.: Affective images of tourism destinations, Journal of travel research, pp. 11-15, (1997)

[18] Castro, C., Armario, E., and Ruiz, D.: The influence of market heterogenity on the relationship between a destination's image and tourists' future behavior, Tourism Management, pp. 175-187, (2007)

[19] Chen, C.: Investigating structural relationships between service quality, perceived value, satisfaction, and behavioral intention for air passengers: Evidence from Taiwan, Transportation Research Part A: Policy and Practice, pp. 709-717, (2008)

[20] Haahti, A. and Yavas, U.: A multi-attribute approach to understanding image of a theme park: The case of SantaPark in Lapland, European Business Review, pp. 390-397, (2004) 
[21] Anton, J.: Customer Relationship Management, New Jersey: Upper Saddle River, (1996)

[22] Kao, Y., Huang, L. and Wu, C.: Effects of theatrical elements on experiential quality and loyalty intentions for theme parks, Asia Pacific Journal of Tourism Research, pp. 163-174, (2008)

[23] Han, H., Back, K., and Barrett, B.: Influencing factors on restaurant customers' revisit intention: The roles of emotions and switching barriers, International Journal of Hospitality Management, (2009)

[24] Aziz, N., Ariffin, A., Osman, N. and Evin, C.: Examining the impact of visitors' emotions and perceived quality towards satisfaction and revisit intention to theme parks, Jurnal Pengurusan, (2012)

[25] Bigne, J., Sanchez, M., and Sanchez, J.: Tourism image, evaluation variables and after purchase behavior: Interrelationship, Tourism Management, (2001)

[26] Fuchs, M. and Weiermair, K.: Destination benchmarking: An indicator-system's potential forexploring guest satisfaction, Journal of Travel Research (2004)

[27] Andreassen, T. and Lindestad, B.: Customer loyalty and complex services: The impact of corporate image on quality, customer satisfaction and loyalty for customers with varying degrees of service expertise, International Journal of Service Industry Management, pp. 7-23, (1998)

[28] Um, S., Chon, K. and Ro, Y.: Antecedents of revisit intention," Annals of Tourism Research, pp. 1141-1158, (2006)

[29] Dörnyei, Z.: Research method in applied linguistics, New York: Oxford University Press, (2007)

[30] Mahfud, S. and Ratmono, D.: Analisis SEM-PLS dengan WarpPLS 3.0, Yogyakarta: Penerbit Andi, (2013)

[31] Hinton, P., McMurray, I. and Brownlow, C.: SPSS Explained, New York: Routledge (Taylor \& Francis Group), (2014)

[32] Fraering, M. and Minor, M.: Sense of comunity: An exploratory study of US consumers of financial services, International Journal of Bank Marketing, vol. 24, no. 5, pp. 284-306, (2006)

[33] Fornell and Larcker, D.: Evaluating structural equation models with unobservable variables and measurement error, Journal of Marketing Research, (1981)

[34] Hair, J., Tatham, R., Anderson, R. and Black, W.: Multivariat Data Analysis (Fifth Edition), London: Prentice-Hall, (1998)

[35] Aydin, S. and Ozer, G.: The analysis of antecedents of customer loyalty in the Turkish mobile telecommunication market, European Journal of Marketing, pp. 910-925, (2005)

[36] Kim, J. and Jin, B.: Korean Consumers' patronage of discount stores: Domestic vs multinational discount store shoppers profiles, Journal of Consumer Marketing, (2001)

[37] Sim, K. and Lee, J.: An examination of visitors' satisfaction on revisiting intention and recommendations: A case study of the national natural recreation forests in Korea, Forest Science and Technology, (2013)

[38] Jayawardhena, C. and Wright, I.: An empirical investigation into e-shopping excitement: Antecedents and effects, European Journal of Marketing, (2009) 